\title{
Involvement of histone $\mathrm{H3}$ phosphorylation via the activation of p38 MAPK pathway and intracellular redox status in cytotoxicity of HL-60 cells induced by Vitex agnus-castus fruit extract
}

\author{
HIDETOMO KIKUCHI $^{1,3,5}$, BO YUAN ${ }^{1,2}$, EISUKE YUHARA ${ }^{1}$, MASAHIKO IMAI $^{1}$, RYOTA FURUTANI ${ }^{1}$, \\ SHIN FUKUSHIMA ${ }^{1}$, SHINGO HAZAMA ${ }^{1}$, CHIEKO HIROBE $^{4}$, KUNIO OHYAMA ${ }^{1}$, \\ NORIO TAKAGI ${ }^{2}$ and HIROO TOYODA ${ }^{1}$
}

\begin{abstract}
Departments of ${ }^{1}$ Clinical Molecular Genetics and ${ }^{2}$ Applied Biochemistry, School of Pharmacy, Tokyo University of Pharmacy and Life Sciences, Hachioji, Tokyo 192-0392; ${ }^{3}$ Faculty of Pharmacy, Yasuda Women's University, Asaminami-ku, Hiroshima 731-0153; ${ }^{4}$ Department of Cultural History, Seisen University, Shinagawa-ku, Tokyo 141-0022, Japan
\end{abstract}

Received February 27, 2014; Accepted April 8, 2014

DOI: 10.3892/ijo.2014.2454

\begin{abstract}
We have demonstrated that an extract from the ripe fruit of Vitex angus-castus (Vitex), might be a promising anticancer candidate. In order to further provide a molecular rationale for clinical development in anticancer therapy, a detailed mechanism underlying the efficacy of Vitex against HL-60 cells was investigated. Vitex induced a dose- and timedependent decrease in cell viability associated with induction of apoptosis and $\mathrm{G}_{2} / \mathrm{M}$ cell cycle arrest, both of which were suppressed by the addition of SB203580, an inhibitor for $\mathrm{p} 38$ MAPK. Furthermore, SB203580 significantly suppressed Vitex-induced phosphorylation of histone $\mathrm{H} 3$, a downstream molecule of p38 MAPK known to be involved in apoptosis induction in tumor cells. Notably, Vitex induced upregulation of intracellular ATP, known to bind its binding pocket inside activated p38 MAPK and to be required for the activation of p38 MAPK pathway. These results, thus, suggest that upregula-
\end{abstract}

Correspondence to: Dr Bo Yuan and Dr Hiroo Toyoda, Department of Clinical Molecular Genetics, School of Pharmacy, Tokyo University of Pharmacy and Life Sciences, 1432-1 Horinouchi, Hachioji, Tokyo 192-0392, Japan

E-mail: yuanbo@toyaku.ac.jp

E-mail: toyoda-h@toyaku.ac.jp

Present address: ${ }^{5}$ Department of Clinical Dietetics and Human Nutrition, Faculty of Pharmaceutical Sciences, Josai University, Sakado, Saitama 350-0295, Japan

Abbreviations: MAPK, mitogen-activated protein kinase; ROS, reactive oxygen species; NADPH oxidase, nicotinamide adenine dinucleotide phosphate oxidase; SnPP, tin protoporphyrin IX dichloride; HO-1, heme oxygenase-1

Key words: Vitex angus-castus, apoptosis, $\mathrm{G}_{2} / \mathrm{M}$ phase arrest, $\mathrm{p} 38$ MAPK, histone H3 phosphorylation, intracellular redox status, HL-60 cells tion of intracellular ATP and phosphorylation of histone $\mathrm{H} 3$ are closely associated with the activation of p38 MAPK pathway, consequently contributing to Vitex-mediated cytotoxicity. Intriguingly, a significant decrease of intracellular ROS levels and downregulation of expression level of gp91 ${ }^{\text {phox }}$, an important component of NADPH oxidase, were observed in Vitex-treated cells. A greater decline in ROS levels along with enhanced apoptosis was observed after treatment with Vitex in combination with SnPP, an inhibitor specific for HO-1. Since NADPH oxidase and HO-1 are closely correlated to redox status associated with intracellular ROS levels, the two enzymes are suggested to be implicated in Vitex-mediated cytotoxicity in HL-60 cells by regulating ROS generation. We also suggest that activation of the p38 MAPK pathway may be dependent on the alterations of intracellular ATP levels, rather than that of intracellular ROS levels. These results may have important implications for appropriate clinical uses of Vitex and provide novel insights into the interaction between Vitex and other conventional drugs capable of affecting intracellular redox status.

\section{Introduction}

Although advances in science and technology have replaced raw herbs and/or herbal compounds with powerful synthetic drugs including molecular target-based drugs in cancer therapy, still the issue of concern is resistance, disease relapse and side effects of drugs in a clinical setting. These cancerrelated deficits have led many cancer patients to look for potential cures outside the mainstream of Western medical treatments in order to maintain their quality of life $(1,2)$. In this regard, herbal and other botanical remedies have been historically used by cancer patients in efforts to control their disease progression or to manage symptoms associated with cancer and cancer treatments $(1,2)$. Mixtures of compounds interacting each other produced by plants have provided important combination therapies that affect multiple pharmacological targets simultaneously, resulting in substantial clinical efficacy 
beyond the reach of single compound-based drugs $(2,3)$. The ideology of wanting to assign a specific biological activity to a specific compound has slowed acceptance of the idea of multicomponent therapies in Western medicine (2). Therefore, rediscovering the mechanisms underlying the efficacy of herbal drugs or extracts will not only have important implications for appropriate clinical use of these traditional medicines, but also provide novel insight into the interaction between these traditional medicines and conventional drugs due to the fact that they may be counterproductive when used by patients on chemotherapy or on other prescription medications $(1,2,4)$.

We have investigated the antiproliferative activity of naturally derived compounds against the growth of various types of cancer cells. Of these, Vitex, an extract from the ripe fruit of Vitex agnus-castus, has attracted great attention (5-10). V. agnus-castus is a shrub of the Lamiaceae family (previously known as Verbenaceae family) and found naturally in the Middle East and Southern Europe and China. Ripe fruit of V.agnus-castus has traditionally been used to treat patients with moderate to severe premenstrual syndrome in Europe as well as in China, and demonstrated to be well tolerated and effective $(11,12)$. In addition, we have previously demonstrated that Vitex exhibits cytotoxic activities against various types of solid tumor cells, such as KATO-III (a human gastric signet ring carcinoma cell line), COLO 201 (a human colon adenocarcinoma cell line) and MCF-7 (a human breast carcinoma cell line) $(9,10)$. We further demonstrated that the levels of cytotoxic activity of Vitex were attributed to growth rate of the respective cells, the cells with faster growth rate were more susceptible to Vitex cytotoxicity (9). More importantly, no apparent cytotoxicity was observed in non-tumor cells, such as human uterine cervical canal fibroblast (HCF), human embryo fibroblast (HE-21) and peripheral blood mononuclear cells (PBMNCs) from healthy volunteers when treated with concentrations showing significant cytotoxicity in tumor cells $(6,9,13)$. We recently demonstrated that cytotoxicity of Vitex correlated with differentiation status in leukemia cell lines (13), however, to date, the effects of Vitex on hematopoietic cell line have not been characterized in detail.

We have previously demonstrated that oxidative stress is implicated in KATO-III cell apoptosis induced by Vitex (10), but not in COLO 201 cells (7). We recently also demonstrated that cytotoxicity induced by casticin, a major component of Vitex, in HL-60 cells was independent of reactive oxygen species (ROS) generation (14). Therefore, there is much interest in the alteration of intracellular ROS levels in HL-60 cells exposed to Vitex, since ROS have been widely believed to play a pivotal role in a wide variety of cellular functions, including cell proliferation, differentiation and apoptosis, in both normal and cancer cells $(15,16)$. Indeed, it has been demonstrated that nicotinamide adenine dinucleotide phosphate (NADPH) oxidase, which was described for the first time in professional phagocytes responsible for generation a large burst of superoxide to kill the ingested pathogens (16-18), plays a critical role in the survival of HL-60 cells via ROS generation (19).

In the current study, we first investigated the effects of Vitex on the human promyelocytic cell line HL-60, in view of cell viability, apoptosis induction and cell cycle arrest. Since we recently demonstrated that casticin induced cytotoxicity in HL-60 cells through p38 mitogen-activated protein kinase
(MAPK) signaling pathway (14), the details of whether p38 MAPK is implicated in Vitex-mediated cytocidal effects in the cells were also investigated using its specific inhibitor, SB203580. We further investigated the alteration of intracellular ROS levels in Vitex-treated HL-60 cells. We also investigated whether NADPH oxidase and heme oxygenase-1 (HO-1), a stress-responsive gene closely correlated with cellular redox status, are involved in the regulation of intracellular redox status along with cytotoxicity in Vetix-treated HL-60 cells using their respective inhibitor.

\section{Materials and methods}

Materials. Casticin was obtained from ChromaDex (Irvine, CA, USA). Fetal bovine serum (FBS) was purchased from Nichirei Biosciences (Tokyo, Japan). RPMI-1640 medium, phenazine methosulfate (PMS) and an RNA extraction kit, Isogen were obtained from Wako Pure Chemical Industries (Osaka, Japan). Moloney murine leukemia virus reverse transcriptase (M-MLV RT) and dichlorofluorescin diacetate (DCFH-DA) were purchased from and Invitrogen (Carlsbad, CA, USA). Random primer was purchased from Takara Bio, (Shiga, Japan). GoTaq DNA polymerase was purchased from Promega (Madison, WI, USA). Propidium iodide (PI) and 2,3-bis(2-methoxy-4nitro-5-sulfophenyl)-5-[(phenylamino)carbonyl]-2H-tetrazolium hydroxide (XTT), were purchased from Sigma-Aldrich (St. Louis, MO, USA). Both SB203580, a specific inhibitor of p38 MAPK, and its negative control SB202474 were purchased from Calbiochem (La Jolla, CA, USA). Tin protoporphyrin IX dichloride (SnPP), an inhibitor specific for HO-1, was purchased from Alexis Biochemicals (San Diego, CA, USA).

Preparation of an ethanol extract from dried ripened V.agnuscastus fruits (Vitex). Preparation of Vitex was carried out according to the methods described previously $(9,13)$. Briefly, dried ripened $V$. agnus-castus fruit from Israel was gently triturated. The extract was prepared from $1 \mathrm{~g}$ of the triturate with $10 \mathrm{ml}$ of ethanol under reflux for $2 \mathrm{~h}$. The extract was then cooled, filtered, evaporated and dried in a vacuum desiccator, a product of which was designated as Vitex. The yield of Vitex was $0.08-0.1 \mathrm{~g}$ from $1 \mathrm{~g}$ of dried fruit.

Cell culture and treatment. HL-60 cells were obtained from the Health Science Research Resources Bank (Tokyo, Japan). Cells were cultured in RPMI-1640 medium supplemented with $10 \%$ heat-inactivated FBS and $100 \mathrm{U} / \mathrm{ml}$ of penicillin and $100 \mu \mathrm{g} / \mathrm{ml}$ of streptomycin at $37^{\circ} \mathrm{C}$ in a humidified atmosphere $\left(5 \% \mathrm{CO}_{2}\right.$ in air). Cells were treated with SB203580, a specific inhibitor of p38 MAPK, and its negative control SB202474 at the indicated concentrations for $1 \mathrm{~h}$ prior to treatment with Vitex in the presence or absence of these reagents. In order to investigate whether HO-1 is involved in Vitex-mediated cytotoxicity, cells were also treated with Vitex in the presence or absence of SnPP.

Cell viability assay. After treatment with Vitex (10, 30 and $50 \mu \mathrm{g} / \mathrm{ml}$ ) for 24 or $48 \mathrm{~h}$, cell viability was measured by the XTT assay as described previously $(5,13)$. Briefly, cells were exposed to Vitex, followed by washing with PBS twice and resuspension in appropriate volume of PBS. An aliquot $(0.2 \mathrm{ml})$ of cell suspension was inoculated into 96-well microplates 
followed by the addition of $50 \mu 1 \mathrm{XTT} / \mathrm{PMS}$ mixed solution (1.5 mM XTT and $0.025 \mathrm{mM}$ PMS). After incubation at $37^{\circ} \mathrm{C}$ for $4 \mathrm{~h}$, plates were mixed on a mechanical plate shaker, and absorbance at $450 \mathrm{~nm}$ was measured with a microplate reader (Safire, Tecan, Switzerland). The relative cell viability was expressed as the ratio of the absorbance of each treatment group against those of the corresponding untreated control group. The $\mathrm{IC}_{50}$ value of Vitex was calculated from the cell proliferation inhibition curve after 24- and 48-h treatment, respectively.

DNA fragmentation analysis. After treatment with Vitex (10, 20, 30, 40 and $50 \mu \mathrm{g} / \mathrm{ml}$ ) for $24 \mathrm{~h}$, DNA extraction and DNA fragmentation analysis were carried out according to a method described previously (20). Briefly, extracted DNA was dissolved in TE buffer (10 mM Tris-HCl, pH 7.8, 1 mM EDTA). These DNA samples (approximately $20 \mu \mathrm{g}$ DNA/20 $\mu \mathrm{l}$ TE buffer) and 100 bp DNA Ladder were electrophoresed, respectively, on a $2 \%$ agarose $\mathrm{X}$ gel (Nippon Gene, Tokyo, Japan), and visualized by ethidium bromide staining, followed by viewing under UV Light Printgraph (ATTO Corp., Tokyo, Japan).

Cell cycle analysis. After treatment with $20 \mu \mathrm{g} / \mathrm{ml}$ of Vitex in the presence or absence of SB203580 or SB202474 for $12 \mathrm{~h}$, cell cycle analysis was performed using a FACSCanto flow cytometer (Becton-Dickinson, CA, USA) according to a method reported previously $(14,21)$. A total of 10,000 events were acquired and cell cycle distribution (sub- $\mathrm{G}_{1}, \mathrm{G}_{0} / \mathrm{G}_{1}, \mathrm{~S}$ and $\mathrm{G}_{2} / \mathrm{M}$ phase fraction) was analyzed by using FlowJo software (Ver. 7.6.5, TreeStar, USA) on the basis of 'Watson Pragmatic' algorithm.

Western blot analysis. Protein samples were separated on SDS-PAGE, followed by transferring to a nitrocellulose membrane as described previously (22). Protein bands were detected using the following primary antibodies: mouse anti-human $\beta$-actin (1:5,000 dilution, Sigma-Aldrich); rabbit anti-human phospho-p38 MAPK (Thr180/Tyr182) (1:1,000 dilution) and rabbit anti-human p38 MAPK (1:1,000 dilution) (Cell Signaling Technology, MA, USA). Blotted protein bands were detected with respective horseradish peroxidase-conjugated secondary antibody and an enhanced chemiluminescence (ECL) western blot analysis system (Amersham Pharmacia Biotech, Buckinghamshire, UK). Relative amounts of the immunoreactive proteins were calculated from the density of the gray level on a digitized image using a program, Multi Gauge Ver. 3.0 (Fujifilm, Tokyo, Japan).

Detection of phosphorylation of histone H3. After treatment with $20 \mu \mathrm{g} / \mathrm{ml}$ of Vitex in the presence or absence of SB203580 or SB202474 (20 $\mu \mathrm{M}$, respectively) for $12 \mathrm{~h}$, the expression levels of phosphorylation of histone $\mathrm{H} 3$ were analyzed using a FACSCanto flow cytometer according to a method reported previously (14). A total of 10,000 events were acquired and analyzed using Diva software.

Measurement of intracellular ATP levels. ATP levels were determined using a 'Cellno' ATP assay reagent (Toyo B-Net, Tokyo, Japan) according to the manufacturer's instructions. Briefly, after treatment with $20 \mu \mathrm{g} / \mathrm{ml}$ of Vitex for $6 \mathrm{~h}$, cells ( $2 \times 10^{5}$ cells) were washed with PBS twice and suspended in
$100 \mu 1$ of PBS. Cell suspension was inoculated into 96-well microtiter plates followed by the addition of $100 \mu \mathrm{l}$ of 'Cellno' ATP assay reagent. After shaking for $1 \mathrm{~min}$ and incubating for $10 \mathrm{~min}$ at room temperature, luminescence was measured in a luminometer as described in our previous report (14).

Measurement of intracellular ROS levels. Intracellular ROS levels were analyzed using DCFH-DA as a ROS-reactive fluorescence probe as described previously (14). In brief, after treatment with $20 \mu \mathrm{g} / \mathrm{ml}$ of Vitex for 3 or $12 \mathrm{~h}$ in the presence or absence of $20 \mu \mathrm{M}$ of SnPP, cells ( $1 \times 10^{6}$ cells) were suspended in $1 \mathrm{ml}$ of PBS with $5 \mathrm{mM}$ DCFH-DA and incubated for $20 \mathrm{~min}$ at $37^{\circ} \mathrm{C}$. Next, cells were washed with PBS twice, and resuspended in $500 \mu \mathrm{l}$ of $2 \mu \mathrm{g} / \mathrm{ml} \mathrm{PI} / \mathrm{PBS}$. A total of 30,000 events were acquired for flow cytometry analysis using a FACSCanto flow cytometer and Diva software.

Reverse transcription-polymerase chain reaction (RT-PCR) analysis. Total RNA isolation and complementary DNA were prepared according to methods described previously with modifications (23). Total RNA was extracted from cells using an RNA extraction kit, Isogen. Complementary DNA was synthesized from $1 \mu \mathrm{g}$ of RNA using 100 pmol random primer and $50 \mathrm{U}$ M-MLV RT in a total volume of $20 \mu \mathrm{l}$, according to the manufacturer's instructions. PCR was performed according to the methods described previously (23). DNA primers for RT-PCR were purchased from Amersham Pharmacia Biotech (Piscataway, NJ, USA); sense primer (5'-GAA TGG GGA AAA ATA AAG GAA TG-3') and antisense primer (5'-ACC CCT TCT TCT TCA TCT GTA GC-3') for gp91 ${ }^{\text {phox }}$ mRNA (24); sense primer (5'-CGC TTC ACC CAG TGG TAC TT-3') and antisense primer (5'-GAG AGC AGG AGA TGC AGG AC-3') for $\mathrm{p} 22^{\text {phox }}$ mRNA (24); and sense primer (5'-CCT TCC TGG GCA TGG AGT CCT G-3') and antisense primer (5'-GGA GCA ATG ATC TTG ATC TTC-3') for $\beta$-actin mRNA (23). PCR was carried out 36, 27 and 21 cycles for gp91 ${ }^{\text {phox }}, \mathrm{p} 22^{\text {phox }}$ and $\beta$-actin mRNA, respectively (45 sec at $94^{\circ} \mathrm{C}$ for denaturation, $45 \mathrm{sec}$ at $60^{\circ} \mathrm{C}$ for annealing and $2 \mathrm{~min}$ at $72^{\circ} \mathrm{C}$ for extension) using a Takara PCR Thermal Cycler Dice (Takara Bio). PCR products and a Tracklt ${ }^{\mathrm{TM}} 100$ bp DNA Ladder as a DNA size marker were electrophoresed on a $2 \%$ UltraPure $^{\mathrm{TM}}$ agarose gel (Invitrogen), respectively, and visualized by ethidium bromide staining, followed by viewing under UV Light Printgraph. The relative expression levels of gp91 ${ }^{\text {phox }}$ or $\mathrm{p} 22^{\text {phox }} / \beta$-actin gene were calculated as the ratios against those at 0 -time using Image $1.46 \mathrm{~m}$ (Wayne Rasband, USA).

Statistical analysis. Data were analyzed using Student's t-test and $\mathrm{p}<0.05$ was considered as statistically significant.

\section{Results}

Contribution of apoptosis induction and cell cycle arrest to Vitex-induced cytotoxicity in HL-60 cells. Since both apoptosis and cell cycle arrest have been demonstrated to contribute to cytocidal effects of substances derived from natural product (25), alteration of cell viability and induction of apoptosis along with cell cycle arrest were investigated in HL-60 cells after treatment with Vitex ranging from 10 to $50 \mu \mathrm{g} / \mathrm{ml}$ for the indicated time. A significant decrease in cell viability was 
A

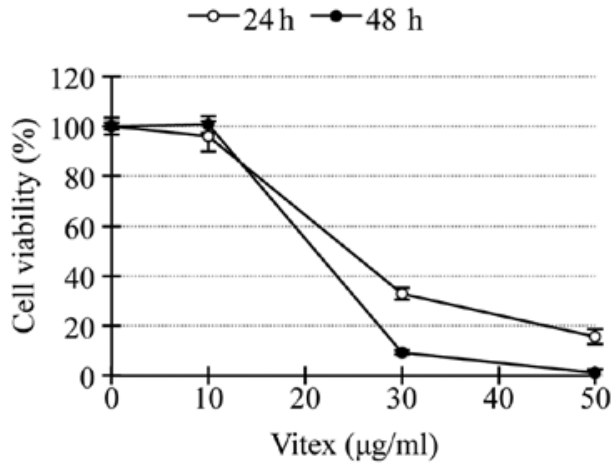

B

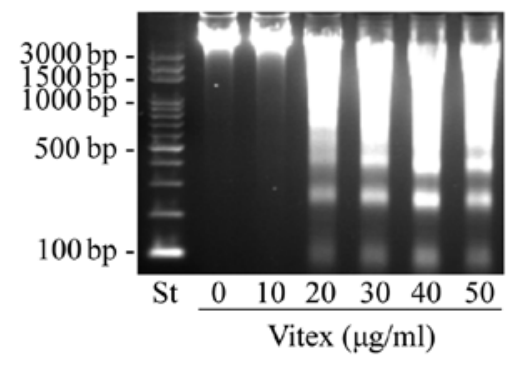

C (1) Control

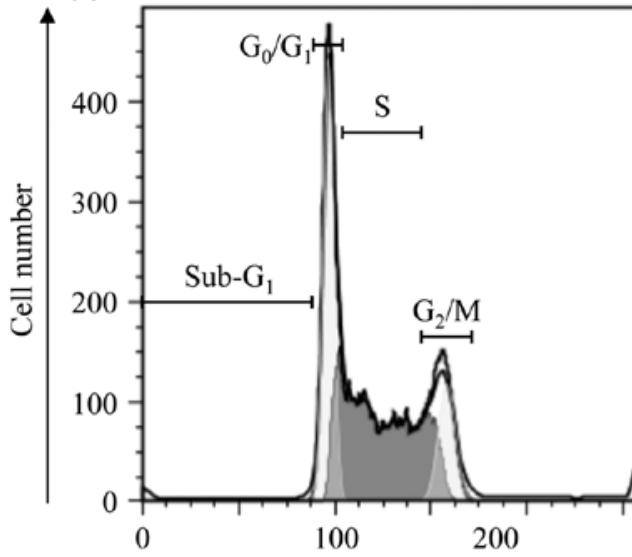

(2) Vitex

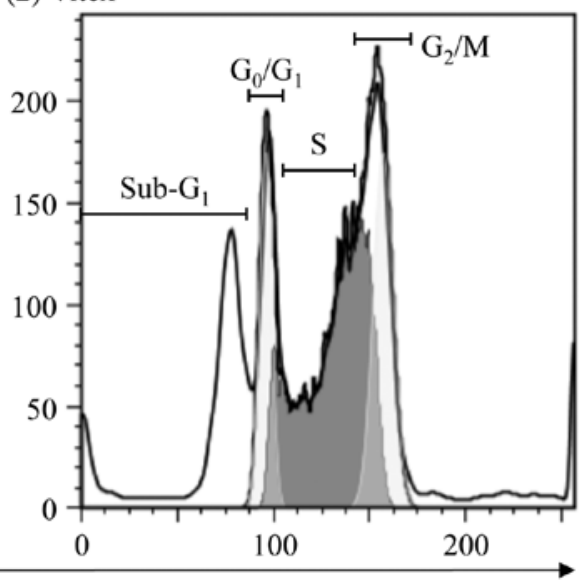

DNA content $(x 1,000)$

Figure 1. Contribution of apoptosis induction and cell cycle arrest to Vitex-induced cytotoxicity in HL-60 cells. (A) Cell viability was determined by XTT assay after treatment with various concentrations of Vitex (10, 30 and $50 \mu \mathrm{g} / \mathrm{ml})$ for 24 (O) or $48 \mathrm{~h}(\bullet)$ as described in Materials and methods. Data are shown as means and SD from three independent experiments. (B) DNA electrophoresis pattern is shown after treatment with indicated concentrations of Vitex for $24 \mathrm{~h}$. Lane St shows 100-bp DNA size markers. A representative electrophoretic profile is shown from three independent experiments. (C) After the treatment with the $\mathrm{IC}_{50}$ value of Vitex at $20 \mu \mathrm{g} / \mathrm{ml}$ for $12 \mathrm{~h}$, cell cycle profiling was performed by FACSCanto flow cytometer as described under Materials and methods. Analyzed data for each sub- $G_{1}, G_{0} / G_{1}, S$ and $G_{2} / M$ phase are shown in the open $\left(G_{0} / G_{1}\right.$ and $G_{2} / M$ phases) and gray area (S phase), respectively. A representative FACS histogram from three separate experiments is shown.

observed in a dose- and time-dependent manner (Fig. 1A). The $\mathrm{IC}_{50}$ values were $20.2 \pm 0.92$ and $18.4 \pm 0.38 \mu \mathrm{g} / \mathrm{ml}$ for 24 - and 48-h treatment, respectively. A significant difference of the $\mathrm{IC}_{50}$ values was observed between two time points $(\mathrm{p}<0.01)$. DNA fragmentation was observed at concentrations starting from $20 \mu \mathrm{g} / \mathrm{ml}$ of Vitex at $24 \mathrm{~h}$ (Fig. 1B). Flow cytometric analysis also showed a significant accumulation of cells in sub- $\mathrm{G}_{1}$ phase after treatment with the $\mathrm{IC}_{50}$ value of Vitex at $20 \mu \mathrm{g} / \mathrm{ml}$ for $12 \mathrm{~h}$ (Fig. 1C), in agreement with results in Fig. 1B. Moreover, $\mathrm{G}_{2} / \mathrm{M}$ cell cycle arrest along with a significant decrease in the number of cells in both $G_{0} / G_{1}$ and $S$ phase was observed simultaneously (Fig. 1C).

Effects of p38 MAPK inhibitor on Vitex-induced apoptosis and cell cycle arrest in $H L-60$ cells. We recently demonstrated that casticin, one of major components of Vitex, induced cytocidal effects in HL-60 cells through p38 MAPK pathway (14). In order to investigate whether the pathway is primarily involved in the effects of Vitex, alteration of apoptosis induction and cell cycle arrest were first determined in the cells after treatment with $20 \mu \mathrm{g} / \mathrm{ml}$ of Vitex in the presence or absence of $20 \mu \mathrm{M} \mathrm{SB} 203580$ for $12 \mathrm{~h}$. As shown in Fig. 2A (panel 4), $\mathrm{B}$ and $\mathrm{C}$, the apoptosis induction and cell cycle arrest were reconfirmed by the increase in the number of cells in sub- $\mathrm{G}_{1}$, $\mathrm{G}_{2} / \mathrm{M}$ phase and the decrease in the number of cells in both $\mathrm{G}_{0} / \mathrm{G}_{1}$ and $\mathrm{S}$ phase, respectively. The addition of SB203580 not only significantly suppressed the apoptosis induction, but also corrected cell cycle arrest at $\mathrm{G}_{2} / \mathrm{M}$ phase, concomitant with an increase in the number of cells in both $G_{0} / G_{1}$ and $S$ phase [Fig. 2A (panel 5), B and C]. A similar phenomenon was not observed in the presence of SB202474 [Fig. 2A (panel 6), B and C]. SB203580 and SB202474 per se showed no influence on apoptosis and cell cycle arrest in HL-60 cells [Fig. 2A (panels 2 and 3), B and C].

Detection of phosphorylation of p38 MAPK in Vitex-treated $H L-60$ cells. In order to further investigate the details of involvement of p38 MAPK signaling pathway in Vitexmediated cytotoxicity in HL-60 cells, the activation of p38 MAPK was assessed by western blot analysis. Similar to our previous results $(14,26)$, endogenous p38 MAPK activation was observed in untreated HL-60 cells based on the detection of a 
A

(1) Control

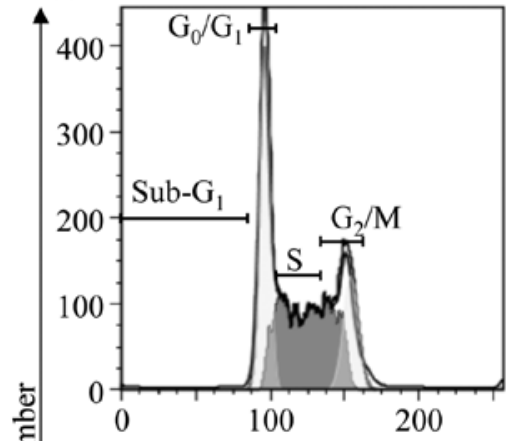

(4) Vitex

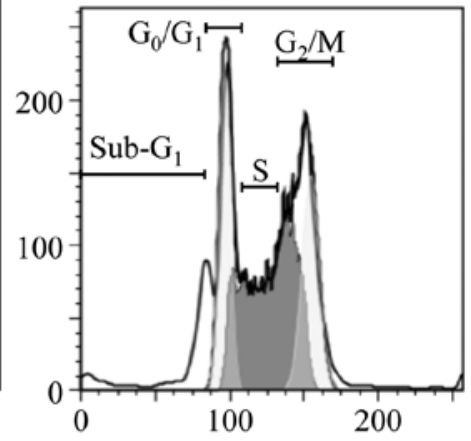

(2) SB203580

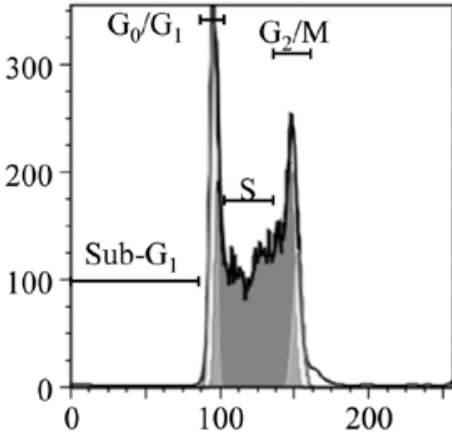

(5) SB203580/Vitex

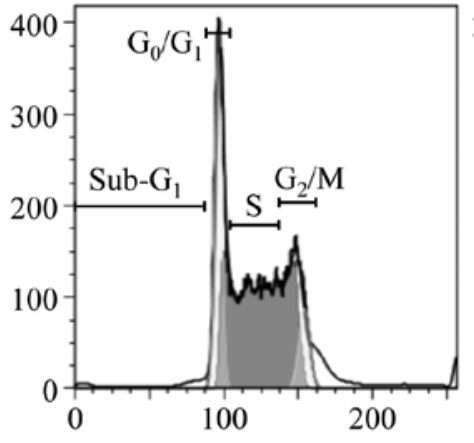

(3) SB202474

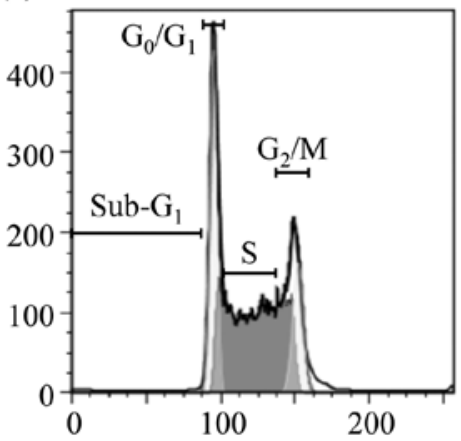

(6) SB202474/Vitex

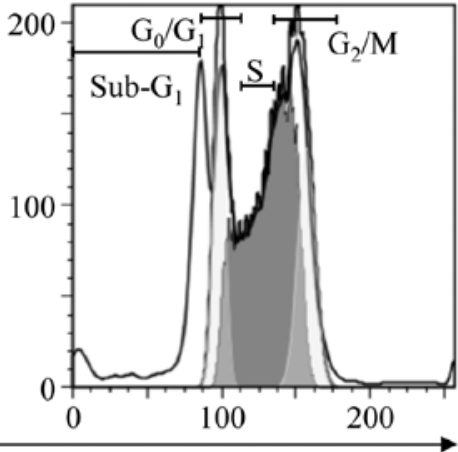

DNA content $(x 1,000)$
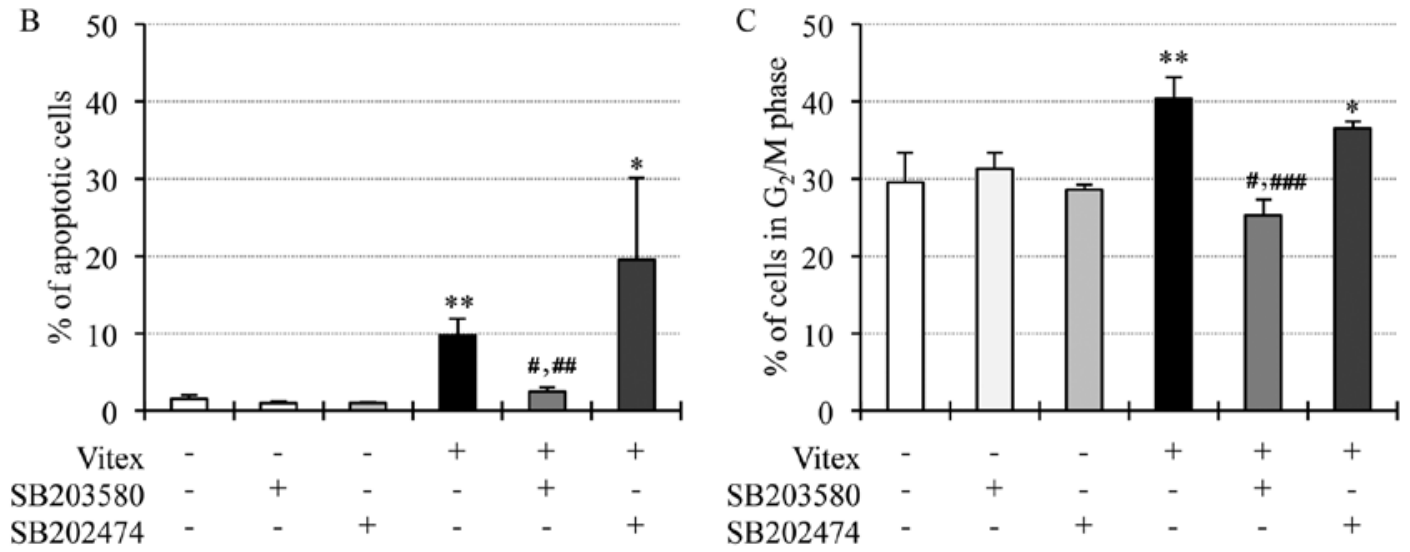

Figure 2. Effect of p38 MAPK inhibitor on Vitex-induced apoptosis and cell cycle arrest in HL-60 cells. (A) After the treatment with $20 \mu \mathrm{g} / \mathrm{ml}$ of Vitex for $12 \mathrm{~h}$ in the presence or absence of SB203580 $(20 \mu \mathrm{M})$ or SB202474 $(20 \mu \mathrm{M})$, cells were collected and then subjected to flow cytometric analysis. (B and C) Percentage of cells at sub- $\mathrm{G}_{1}$ and $\mathrm{G}_{2} / \mathrm{M}$ phase, respectively, determined as described in Fig. 1. Experiments were carried out in triplicate, and results are shown as mean \pm SD. ${ }^{*}$ p $<0.05$ and ${ }^{* *}$ p $<0.01$ vs. control; ${ }^{\#}$ p $<0.01$ vs. Vitex alone; ${ }^{\# \#} \mathrm{p}<0.05$ and ${ }^{\# \# \#}$ p $<0.01$ vs. SB202474/Vitex.

distinct protein band corresponding to phospho-p38 MAPK (Fig. 3). Unexpectedly, although a trend towards increased expression level of phospho-p38 MAPK was observed in $20 \mu \mathrm{g} / \mathrm{ml}$ of Vitex-treated HL-60 cells, there was no significant difference in its expression levels between Vitex-treated and untreated cells, indicating that exposure to Vitex did not affect the degree of p38 MAPK activation (Fig. 3). Moreover, no change in the expression levels of total p38 MAPK was observed in untreated or treated cells.

Suppression of Vitex-induced phosphorylation of histone $\mathrm{H3}$ by $\mathrm{p} 38$ MAPK inhibitor in $\mathrm{HL}-60$ cells. We recently demon- strated that phosphorylation of histone $\mathrm{H} 3$ was observed in casticin-treated HL-60 cells, and suppressed by the addition of SB203580, suggesting that phosphorylation of histone H3 associated with the activation of $\mathrm{p} 38$ MAPK plays a critical role in casticin-mediated cytotoxicity in the cells (14). Therefore, phosphorylation of histone $\mathrm{H} 3$, and its correlation with $\mathrm{p} 38$ MAPK signaling pathway were also investigated in Vitextreated HL-60 cells. Just like the phenomena observed in casticin-treated HL-60 cells (14), a substantial increase in the expression levels of phospho-histone $\mathrm{H} 3$ over the endogenous levels was detected in HL-60 cells exposed to $20 \mu \mathrm{g} / \mathrm{ml}$ of Vitex for $12 \mathrm{~h}$ [Fig. 4A (panels 2 and 5) and B)]. Furthermore, 

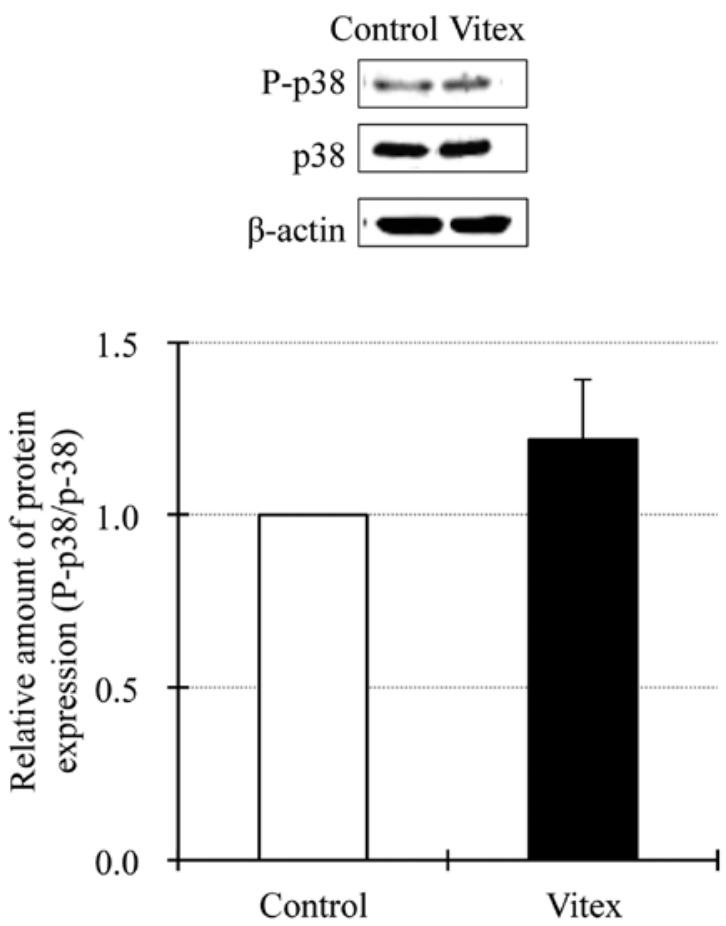

Figure 3. Detection of phosphorylated p38 MAPK in Vitex-treated HL-60 cells. After the treatment with $20 \mu \mathrm{g} / \mathrm{ml}$ of Vitex for $6 \mathrm{~h}$, the expression profiles of phospho-p38 MAPK (active form of p38, P-p38), p38 MAPK (total p38) and $\beta$-actin proteins in HL-60 cells were analyzed as described in the text. The expression levels were expressed as the ratios between P-p38 and p38 protein expression levels, and were compared with those of the control group. Data are shown as mean \pm SD from three independent experiments. the addition of $20 \mu \mathrm{M}$ SB203580, but not SB202474, significantly suppressed Vitex-mediated phosphorylation of histone H3 [Fig. 4A (panels 6 and 7) and B]. SB203580 and SB202474 per se showed no influence on the expression levels of phosphorylation of histone H3 in HL-60 cells [Fig. 4A (panels 3 and 4), B and C].

Upregulation of intracellular ATP level in Vitex-treated $H L-60$ cells. Since binding of ATP to its binding pocket inside the activated p38 MAPK has been reported to be required for the activation of downstream molecules of p38 MAPK (27, 28), the alteration of intracellular ATP level was determined in HL-60 cells after treatment with $20 \mu \mathrm{g} / \mathrm{ml}$ of Vitex for $6 \mathrm{~h}$. As shown in Fig. 5, intercellular ATP level was significantly upregulated in Vitex-treated cells when compared to that in untreated cells, similar to the phenomena observed in casticintreated HL-60 cells (14).

Involvement of gp91phox in Vitex-mediated reduction of intracellular ROS levels in HL-60 cells. FACS analysis using DCFH-DA as a ROS-reactive fluorescence probe showed a significant time-dependent decrease in the intracellular ROS levels after treatment with $20 \mu \mathrm{g} / \mathrm{ml}$ of Vitex for 3 and $12 \mathrm{~h}$ (Fig. 6A). In this regard, it is interesting to note that NADPH oxidase exists in undifferentiated HL-60 cells, and that its mediated generation of ROS is critically required for survival of the cells (19). Therefore, the expression levelsof gp91 $91^{\text {phox }}$ and p22 $2^{\text {phox }}$, important subunits of NADPH oxidase, were investigated in HL-60 cells when treated with $20 \mu \mathrm{g} / \mathrm{ml}$ of Vitex for
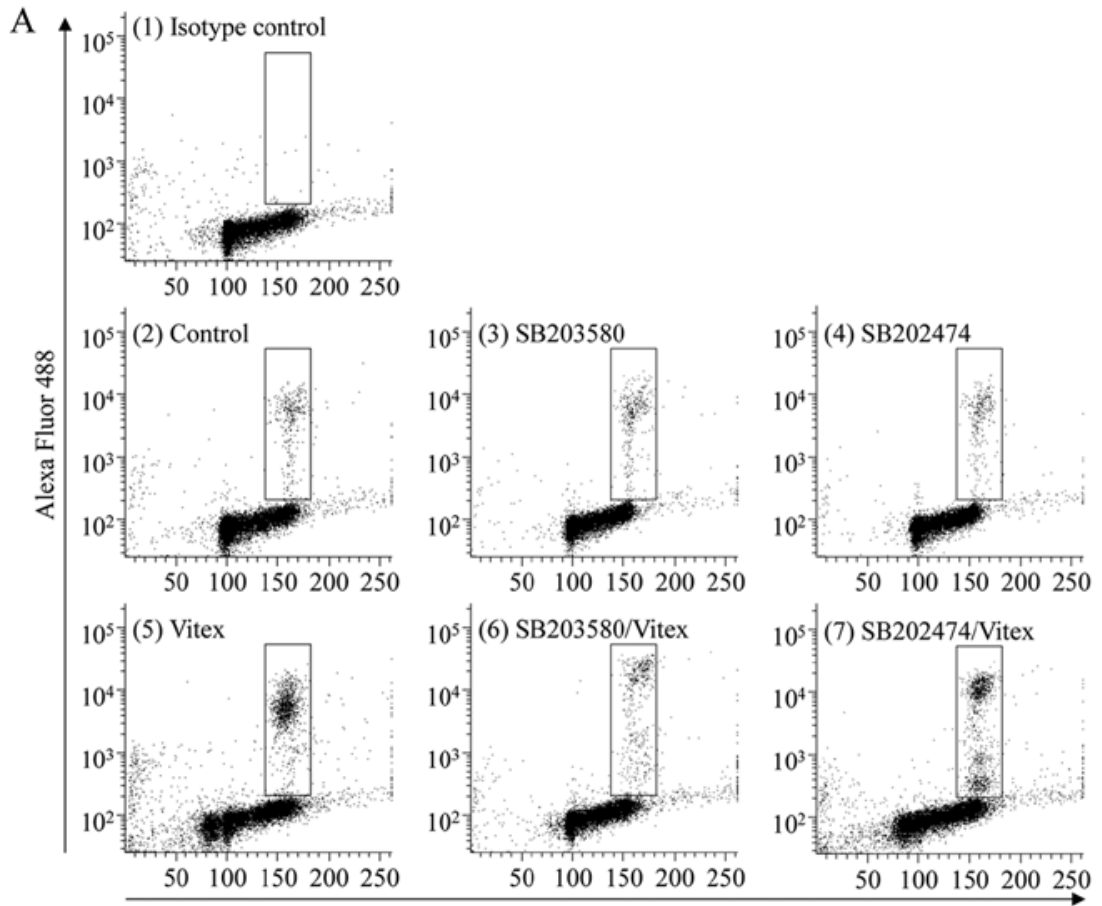

DNA content $(x 1,000)$

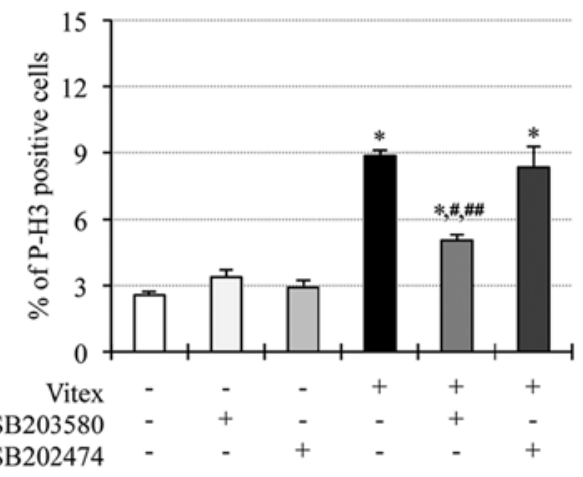

Figure 4. Suppression of Vitex-induced phosphorylation of histone H3 by p38 MAPK inhibitor in HL-60 cells. (A) After the treatment with $20 \mu \mathrm{g} / \mathrm{ml}$ of Vitex for $12 \mathrm{~h}$ in the presence or absence of SB203580 or SB202474 $(20 \mu \mathrm{M}$, respectively), the phosphorylation of histone H3 (P-H3) in HL-60 cells was analyzed as described in the text. (B) Percentage of P-H3 positive cells is shown. Experiments were carried out in triplicate and results are shown as mean \pm SD. ${ }^{*} \mathrm{p}<0.01$ vs. control; ${ }^{\#} \mathrm{p}<0.01$ vs. Vitex alone; ${ }^{\# \#} \mathrm{p}<0.05$ vs. SB202474/Vitex. 


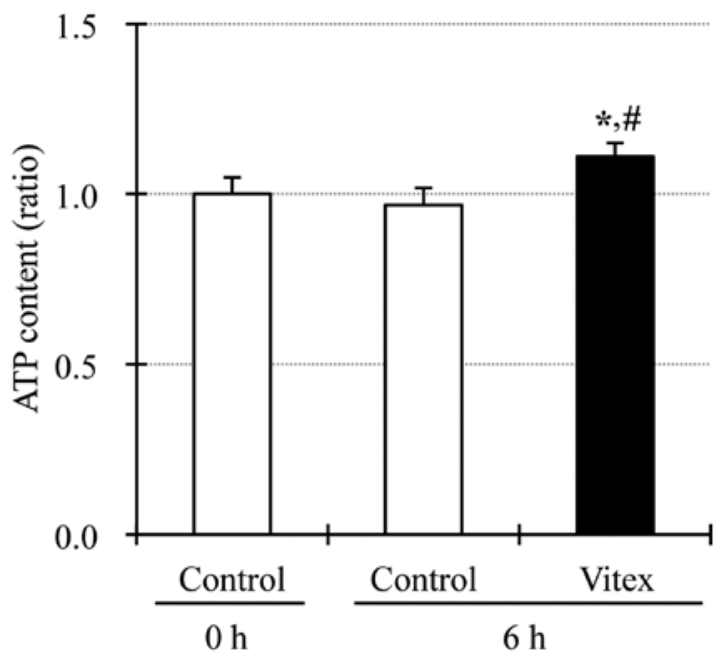

Figure 5. Upregulation of intracellular ATP level in Vitex-treated HL-60 cells. After the treatment with $20 \mu \mathrm{g} / \mathrm{ml}$ of Vitex for $6 \mathrm{~h}$, intracellular ATP content was determined as described in the text. Relative amounts were calculated as the ratios of luminescence of treatment group and control at 6-h time point against control at 0 -h time point. Experiments were carried out in triplicate and results are shown as mean $\pm \mathrm{SD}$. ${ }^{*} \mathrm{p}<0.01$ vs. control at 0 -h time point ${ }^{"} \mathrm{p}<0.01$ vs. control at 6-h time point. indicated time. Compared with control groups, a trend towards reduced expression level of gp91 ${ }^{\text {phox }}$, but not $\mathrm{p} 22^{\text {phox }}$ mRNA was observed in Vitex-treated HL-60 cells throughout the periods of treatment (Fig. 6B-D). Notably, a significant decrease in the expression level of gp91 ${ }^{\text {phox }}$ mRNA was observed at 1- and 3-h post-treatment (Fig. 6B and C). In contrast, as shown Fig. 6B and $\mathrm{D}$, similar phenomena were not observed in the cells treated with $0.3 \mu \mathrm{g} / \mathrm{ml}$ of casticin, the $\mathrm{IC}_{50}$ value of casticin after 24-h treatment as described in our previous report (13).

Enhancement of Vitex-induced cytotoxicity by tin protoporphyrin IX dichloride (SnPP), a HO-1 specific inhibitor, in HL-60 cells. HO-1, a stress-associated gene, is well known to play a critical role in the regulation of intracellular redox status through its biologically active products, such as iron ion, carbon monoxide and biliverdin $(29,30)$. Therefore, whether HO-1 is involved in the regulation of redox status along with cytotoxicity in Vitex-treated HL-60 cells was evaluated. After treatment with $20 \mu \mathrm{g} / \mathrm{ml}$ of Vitex and $20 \mu \mathrm{M}$ of SnPP, alone or combination, for indicated time, alteration of the intracellular ROS levels and cell viability were investigated, respectively. As shown in Fig. 7A, compared to control groups, a signifi-
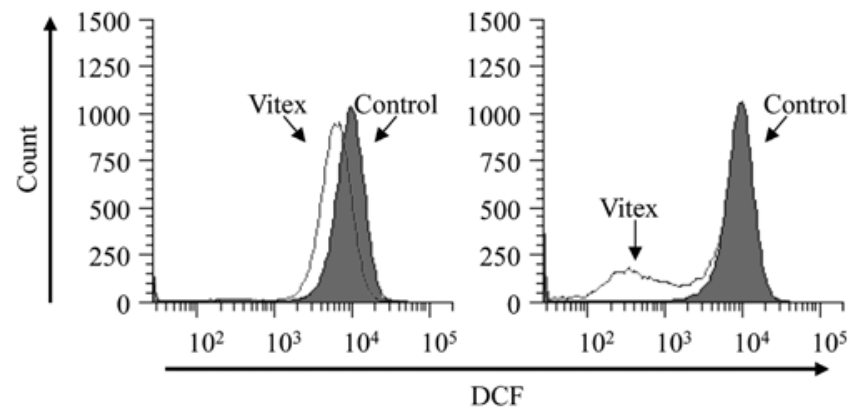

B
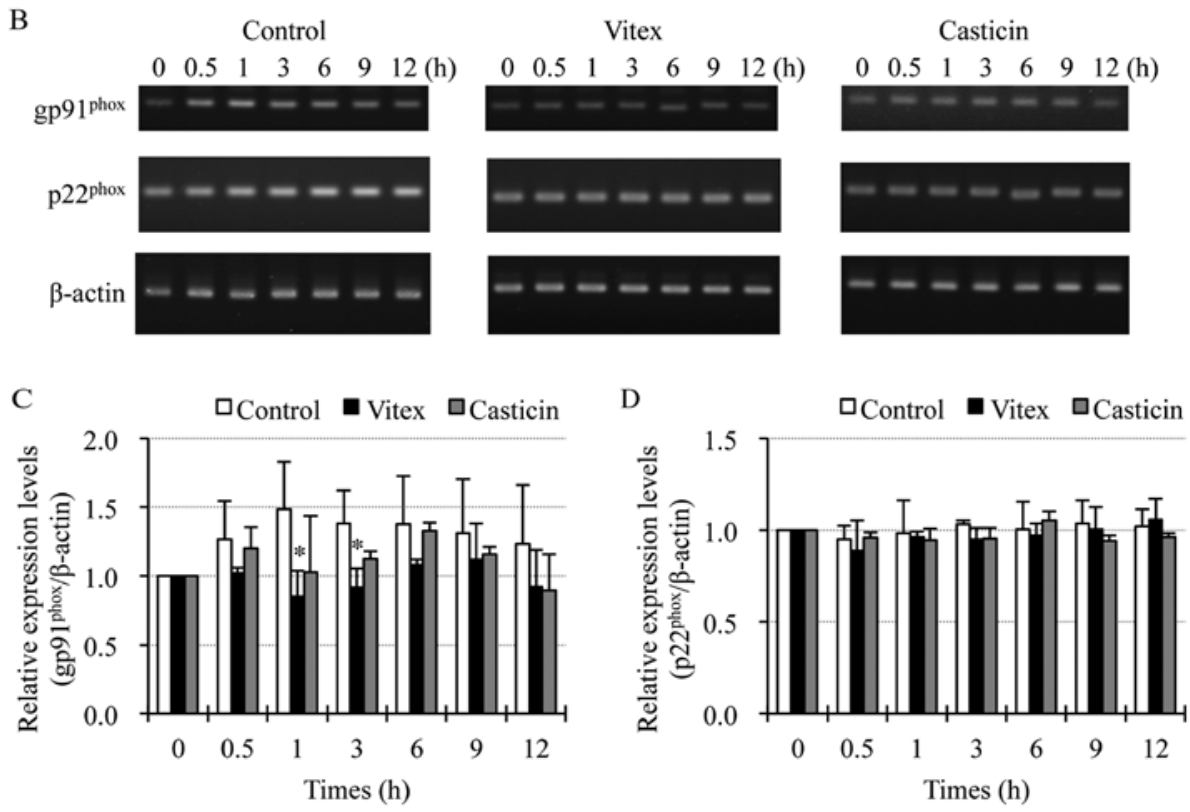

Figure 6. Involvement of gp91 phox in Vitex-mediated reduction of intracellular ROS levels in HL-60 cells. (A) After the treatment with $20 \mu \mathrm{g} / \mathrm{ml}$ of Vitex for 3 or $12 \mathrm{~h}$, cells were incubated with DCFH-DA, a fluorescence probe for ROS and analyzed by FACSCanto flow cytometer. A representative FACS profile from three separate experiments is shown. (B) After treatment with Vitex $(20 \mu \mathrm{g} / \mathrm{ml})$ or casticin $(0.3 \mu \mathrm{g} / \mathrm{ml})$ for indicated time, the expression profiles of gp91 ${ }^{\text {phox }}$ and p22 $2^{\text {phox }}$ mRNA was assessed by RT-PCR, followed by agarose gel electrophoresis as described in Materials and methods. (C and D) The expression levels were expressed as the ratios between $\mathrm{gp} 91^{\mathrm{phox}} / \mathrm{p} 22^{\text {phox }}$ and $\beta$-actin gene expression levels, and were compared with those of the control group. Data are shown as mean $\pm \mathrm{SD}$ from three independent experiments. ${ }^{*} \mathrm{p}<0.05$ vs. control. 
A (1) Incubation for $3 \mathrm{~h}$
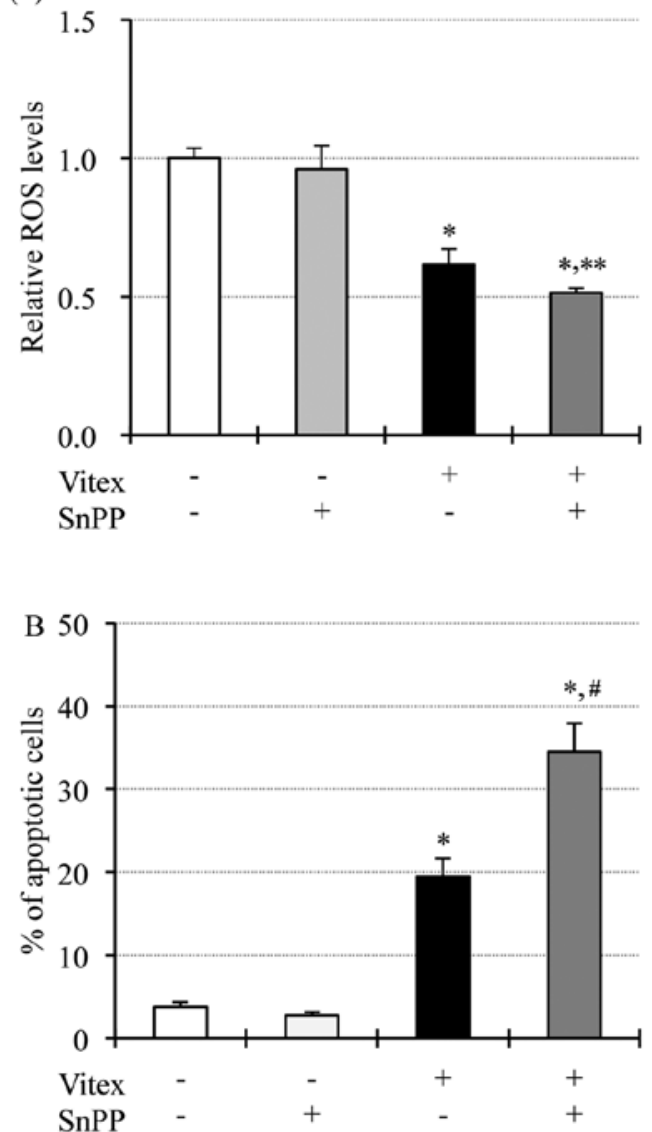

(2) Incubation for $12 \mathrm{~h}$

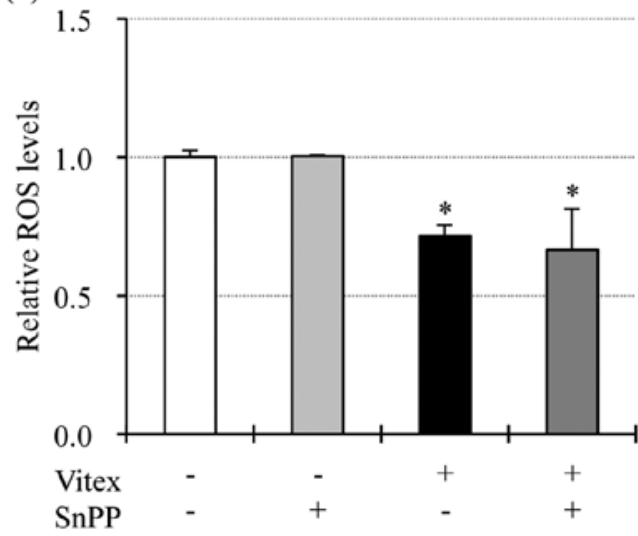

Figure 7. Enhancement of Vitex-induced cytotoxicity by tin protoporphyrin IX dichloride (SnPP), a HO-1 specific inhibitor, in HL-60 cells. (A) After the treatment with Vitex $(20 \mu \mathrm{g} / \mathrm{ml})$ and SnPP $(20 \mu \mathrm{M})$, alone or combination, for 3 or $12 \mathrm{~h}$, alteration of the intracellular ROS levels were investigated as described in Fig. 6A. Relative ROS levels were calculated as the ratios of the mean fluorescence intensity (MFI) of DCF in treatment group and control group at each time-point, as described in our previous report (26). (B) After treatment with Vitex $(20 \mu \mathrm{g} / \mathrm{ml})$ and SnPP $(20 \mu \mathrm{M})$, alone or combination, for $24 \mathrm{~h}$, percentage of apoptotic cells, represented by the accumulation of cells in sub- $\mathrm{G}_{1}$ phase, were calculated as described in Fig. 1. Experiments were carried out in triplicate and results are shown as mean \pm SD from three independent experiments. ${ }^{*} p<0.01$ vs. control; ${ }^{* *} \mathrm{p}<0.05$ and ${ }^{\#} \mathrm{p}<0.01$ vs. Vitex alone.

cant decrease in intracellular ROS levels was reconfirmed in HL-60 cells treated with Vitex alone for 3 and $12 \mathrm{~h}$, and further enhanced by the addition of SnPP at 3-h post-treatment. A small but not significant enhanced decrease in ROS levels was also observed at 12-h post-treatment. These results indicate that biological activity of HO-1 contributes to ROS production in HL-60 cells. Furthermore, the addition of SnPP significantly enhanced the apoptosis induced by Vitex when compared to treatment with Vitex alone for $24 \mathrm{~h}$, indicating the cytoprotective activity of HO-1 (Fig. 7B).

\section{Discussion}

Vitex has traditionally been used in obstetrics and gynecology in Europe as well as in China, and was demonstrated to be well tolerated and effective $(11,12)$. Besides these current clinical uses, we have demonstrated that Vitex exhibits cytotoxic activities against various types of solid tumor cells $(9,10)$. Furthermore, we and others have demonstrated that no apparent cytotoxicity of Vitex and its major component, casticin, was observed in non-tumor cells, PBMNCs and embryo fibroblasts, when treated with concentrations showing significant cytotoxicity in tumors cells $(9,13,31)$. Therefore, we suggest that Vitex/casticin possesses selective cytotoxic activity against tumor cells. More recently, we investigated the cytocidal effects of Vitex/casticin, against leukemia cell lines with a different degree of differentiation, and demonstrated that their cytotoxicity correlated with differentiation status in these cells (13). As a traditional medicine and a promising anticancer candidate, further detailed studies aimed at characterizing the effects of Vitex against tumor cells are eagerly awaited, since the continuous efforts to explore the mechanisms underlying the efficacy of Vitex will provide a molecular rationale for clinical development in anticancer therapy.

In the current study, we demonstrated that Vitex-mediated reduction in cell viability of HL-60 cells was observed in a doseand time-dependent manner. Furthermore, a dose-dependent apoptosis induction, along with an accumulation of cells in $\mathrm{G}_{2} / \mathrm{M}$ phase and a decrease in the number of cells both in $\mathrm{G}_{0} / \mathrm{G}_{1}$ and $\mathrm{S}$ phase, was observed in the Vitex-treated HL-60 cells. All these phenomena are similar to observations in casticintreated HL-60 cells previous reported by us (14), suggesting that as a major component of Vitex, casticin plays a primary role in Vitex-mediated cytocidal effects against HL-60 cells.

Our experimental results regarding the cytotoxicity of casticin against HL-60 cells suggested that the cytotoxicity 
associated with apoptosis and cell arrestwas mediated by p38 MAPK pathway, in which intracellular ATP levels and phosphorylation of histone $\mathrm{H} 3$ played critical roles (14). In this regard, it is interesting to note that the addition of SB203580, an inhibitor for p38 MAPK, clearly not only corrected Vitex-mediated cell cycle arrest but also efficiently suppressed apoptosis induction, reconfirming that casticin primarily contributes the cytocidal effects induced by Vitex in HL-60 cells. Very similar to that in casticin-treated HL-60 cells (14), although almost no alteration of the expression level of phospho-p38 MAPK was observed in the cells treated with Vitex, a substantial increase in the expression levels of phospho-histone $\mathrm{H} 3$ over the endogenous levels was detected. It should be noted that histone $\mathrm{H} 3$ phosphorylation is implicated in arsenic trioxide-induced apoptosis in human acute promyelocytic leukemia NB4 cells and gliotoxin-induced apoptosis in mouse thymocytes, respectively $(32,33)$. Furthermore, the addition of SB203580 significantly suppressed Vitex-induced phosphorylation of histone $\mathrm{H} 3$, suggesting that histone $\mathrm{H} 3$ is one of downstream molecules of p38 MAPK pathway. In fact, it has been demonstrated that in response to various stimuli, activated p38 MAPK regulates the immediate early gene expression and other cellular responses by phosphorylating various substrates, including chromatin proteins, and transcription factors $(34,35)$. We further demonstrated that intracellular ATP levels were significantly upregulated in Vitex-treated HL-60 cells when compared to those in untreated cells. Based on the fact that SB203580 has been reported to compete with ATP for binding to the active form of p38 MAPK, and consequently blocks the p38 MAPK activity in downstream molecules $(27,28)$, we suggest that upregulation of intracellular ATP levels and phosphorylation of histone $\mathrm{H} 3$ are closely associated with the activation of $\mathrm{p} 38$ MAPK signaling pathway, consequently contributing to Vitexmediated cytocidal effects against HL-60 cells. Collectively, these findings demonstrated that in view of apoptosis induction and cell cycle arrest, the experimental data obtained in Vitex- and casticin-treated HL-60 cells showed a close similarity, strongly suggesting that casticin plays a primary role in apoptosis induction and cell cycle arrest induced by Vitex in HL-60 cells.

We further demonstrated a significant time-dependent decrease in the intracellular ROS levels in Vitex-treated HL-60 cells. Intriguingly, this result is the opposite to our recent report showing that increased intracellular ROS production was observed in casticin-treated HL-60 cells, although casticin-induced cytotoxicity in the cells is independent of ROS generation (14). These results thus suggested that other phytochemicals, rather than casticin, contributed to the decline in the intracellular ROS levels. Indeed, flavonoids isolated from $V$. agnus-castus, such as isoorientin, 2 "- $O$-trans-caffeoylisoorientin, 6"- $O$-trans-caffeoylisoorientin and luteolin 7-O-glucoside, have been demonstrated to possess free radical scavenging activity (36). Concomitantly, the expression level of gp91 ${ }^{\text {phox }}$, an important component of NADPH oxidase, was also suppressed by the treatment with Vitex. It has been demonstrated that NADPH oxidasemediated generation of ROS is critically required for survival of undifferentiated HL-60 cells (19). Similar to the previous report, our experimental data also demonstrated that treatment with diphenyleneiodonium (an inhibitor of NADPH oxidase) alone resulted in a significant and dose-dependent decline in the survival of HL-60 cells (data not shown). Collectively, these results suggest that Vitex exhibits its cytocidal effects via downregulation of intracellular ROS levels, which is at least partially attributed to the suppression of NADPH oxidase. It is of interest to note that a greater decline in the ROS levels along with enhanced induction of apoptosis was observed in HL-60 cells treated with Vitex in combination with SnPP, an inhibitor specific for HO-1. HO-1 has been well recognized as a proproliferative molecule in various types of tumor cells (37), although its antiproliferative effects of HO-1 in tumor cells have also been conducted (38). Taking these previous results and our observations into account, we suggest that HO-1 exhibits cytoprotective activity through keeping ROS levels required for survival of HL-60 cells. Since iron ion is well known to be responsible for the generation of ROS, iron ion, one of biologically active products of $\mathrm{HO}-1$, is thus proposed to contribute to maintain the balance of ROS levels in the cells. Further investigation of the molecular details for the maintenance is ongoing.

In conclusion, we demonstrated that apoptosis and cell cycle arrest are involved in Vitex-induced cytocidal effects in HL-60 cells, and that histone $\mathrm{H} 3$ phosphorylation via the activation of p38 MAPK pathway is implicated in the cytocidal effects. Based on our recent study on the cytotoxicity of casticin (14), we further confirmed that casticin, as a major component of Vitex, plays a primary role in Vitex-mediated cytotoxicity in HL-60 cells. Intriguingly, we demonstrated that Vitex significantly downregulated the intracellular ROS levels, which appeared to be related to the suppression of NADPH oxidase. Furthermore, treatment with Vitex in combination with SnPP resulted in a greater decline in the ROS levels along with enhanced induction of apoptosis. Therefore, these results suggest that intracellular redox status is a critical factor in determining the fate of Vitextreated cells. It has been reported that p38 MAPK is considered to be a sensor of moderate oxidative stress, and was activated in a ROS-dependent manner (39). Based on the downregulation of intracellular ROS levels and upregulation of intracellular ATP levels, we suggest that activation of p38 MAPK pathway might be dependent on the alterations of intracellular ATP levels, rather than that of intracellular ROS levels, details of investigation into the mechanism is ongoing. Furthermore, these results may have important implications for appropriate clinical use of Vitex and provide novel insight into the interaction between Vitex and other conventional drugs capable of affecting intracellular redox status.

\section{Acknowledgements}

This study was supported in part by grants from the Ministry of Education, Culture, Sports, Science and Technology and by the Promotion and Mutual Aid Corporation for Private Schools of Japan.

\section{References}

1. Cassileth B, Yeung KS and Gubili J: Herbs and other botanicals in cancer patient care. Curr Treat Options Oncol 9: 109-116, 2008.

2. Schmidt BM, Ribnicky DM, Lipsky PE and Raskin I: Revisiting the ancient concept of botanical therapeutics. Nat Chem Biol 3: 360-366, 2007. 
3. Wang L, Zhou GB, Liu P, Song JH, Liang Y, Yan XJ, Xu F, Wang BS, Mao JH, Shen ZX, Chen SJ and Chen Z: Dissection of mechanisms of Chinese medicinal formula Realgar-Indigo naturalis as an effective treatment for promyelocytic leukemia. Proc Natl Acad Sci USA 105: 4826-4831, 2008.

4. HemaIswarya $S$ and Doble M: Potential synergism of natural products in the treatment of cancer. Phytother Res 20: 239-249, 2006.

5. Imai M, Kikuchi H, Denda T, Ohyama K, Hirobe C and Toyoda H: Cytotoxic effects of flavonoids against a human colon cancer derived cell line, COLO 201: a potential natural anti-cancer substance. Cancer Lett 276: 74-80, 2009.

6. Imai M, Kikuchi H, Yuan B, Aihara Y, Mizokuchi A, Ohyama K, Hirobe $\mathrm{C}$ and Toyoda $\mathrm{H}$ : Enhanced growth inhibitory effect of 5-fluorouracil in combination with Vitex agnus-castus fruits extract against a human colon adenocarcinoma cell line, COLO 201. J Chin Clin Med 6: 14-19, 2011

7. Imai M, Yuan B, Kikuchi H, Saito M, Ohyama K, Hirobe C, Oshima T, Hosoya T, Morita H and Toyoda H: Growth inhibition of a human colon carcinoma cell, COLO 201, by a natural product, Vitex agnus-castus fruits extract, in vivo and in vitro. Adv Biol Chem 2: 20-28, 2012.

8. Yuan B, Imai M, Kikuchi H, Fukushima S, Hazama S, Akaike T, Yoshino Y, Ohyama K, Hu X, Pei X and Toyoda H: Cytocidal effects of polyphenolic compounds, alone or in combination with, anticancer drugs against cancer cells: potential future application of the combinatory therapy. In: Apoptosis and Medicine. Ntuli TM (ed). InTech, Croatia, pp155-174, 2012.

9. Ohyama K, Akaike T, Hirobe C and Yamakawa T: Cytotoxicity and apoptotic inducibility of Vitex agnus-castus fruit extract in cultured human normal and cancer cells and effect on growth. Biol Pharm Bull 26: 10-18, 2003.

10. Ohyama K, Akaike T, Imai M, Toyoda H, Hirobe C and Bessho T: Human gastric signet ring carcinoma (KATO-III) cell apoptosis induced by Vitex agnus-castus fruit extract through intracellular oxidative stress. Int J Biochem Cell Biol 37: 1496-1510, 2005.

11. Ma L, Lin S, Chen R and Wang X: Treatment of moderate to severe premenstrual syndrome with Vitex agnus castus (BNO 1095) in Chinese women. Gynecol Endocrinol 26: 612-616, 2010.

12. Schellenberg R: Treatment for the premenstrual syndrome with agnuscastus fruit extract: prospective, randomised, placebo controlled study. BMJ 322: 134-137, 2001.

13. Kikuchi H, Yuan B, Nishimura Y, Imai M, Furutani R, Kamoi S, Seno M, Fukushima S, Hazama S, Hirobe C, Ohyama K, Hu XM, Takagi N, Hirano T and Toyoda H: Cytotoxicity of Vitex agnuscastus fruit extract and its major component, casticin, correlates with differentiation status in leukemia cell lines. Int J Oncol 43: 1976-1984, 2013

14. Kikuchi H, Yuan B, Yuhara E, Takagi N and Toyoda H: Involvement of histone $\mathrm{H} 3$ phosphorylation through p38 MAPK pathway activation in casticin-induced cytocidal effects against the human promyelocytic cell line HL-60. Int J Oncol 43: 2046-2056, 2013.

15. Schumacker PT: Reactive oxygen species in cancer cells: live by the sword, die by the sword. Cancer Cell 10: 175-176, 2006.

16. Trachootham D, Alexandre J and Huang P: Targeting cancer cells by ROS-mediated mechanisms: a radical therapeutic approach? Nat Rev Drug Discov 8: 579-591, 2009.

17. Wang J and Yi J: Cancer cell killing via ROS: to increase or decrease, that is the question. Cancer Biol Ther 7: 1875-1884, 2008.

18. Yuan B, Yoshino Y, Kaise T and Toyoda H: Application of arsenic trioxide therapy for patients with leukemia. In: Biological Chemistry of Arsenic, Antimony and Bismuth. Sun H (ed) John Wiley and Sons, Ltd., Chichester, pp263-292, 2011.

19. Dong JM, Zhao SG, Huang GY and Liu Q: NADPH oxidasemediated generation of reactive oxygen species is critically required for survival of undifferentiated human promyelocytic leukemia cell line HL-60. Free Radic Res 38: 629-637, 2004.

20. Yuan B, Ohyama K, Bessho T, Uchide N and Toyoda H: Imbalance between ROS production and elimination results in apoptosis induction in primary smooth chorion trophoblast cells prepared from human fetal membrane tissues. Life Sci 82: 623-630, 2008.

21. Kon A, Yuan B, Hanazawa T, Kikuchi H, Sato M, Furutani R, Takagi $\mathrm{N}$ and Toyoda $\mathrm{H}$ : Contribution of membrane progesterone receptor $\alpha$ to the induction of progesterone-mediated apoptosis associated with mitochondrial membrane disruption and caspase cascade activation in Jurkat cell lines. Oncol Rep 30: 1965-1970, 2013.
22. Yuan B, Ohyama K, Takeichi M and Toyoda H : Direct contribution of inducible nitric oxide synthase expression to apoptosis induction in primary smooth chorion trophoblast cells of human fetal membrane tissues. Int J Biochem Cell Biol 41: 1062-1069, 2009.

23. Yuan B, Ohyama K, Bessho T and Toyoda H: Contribution of inducible nitric oxide synthase and cyclooxygenase-2 to apoptosis induction in smooth chorion trophoblast cells of human fetal membrane tissues. Biochem Biophys Res Commun 341: 822-827, 2006.

24. Perner A, Andresen L, Pedersen G and Rask-Madsen J: Superoxide production and expression of $\mathrm{NAD}(\mathrm{P}) \mathrm{H}$ oxidases by transformed and primary human colonic epithelial cells. Gut 52: 231-236, 2003.

25. Reddy L, Odhav B and Bhoola KD: Natural products for cancer prevention: a global perspective. Pharmacol Ther 99: 1-13, 2003

26. Hu XM, Yuan B, Tanaka S, Zhou Q, Onda K, Toyoda H and Hirano T: Involvement of oxidative stress associated with glutathione depletion and p38 mitogen-activated protein kinase activation in arsenic disulfide-induced differentiation in HL-60 cells. Leuk Lymphoma 55: 392-404, 2014.

27. Frantz B, Klatt T, Pang M, Parsons J, Rolando A, Williams H, Tocci MJ, O'Keefe SJ and O'Neill EA: The activation state of p38 mitogen-activated protein kinase determines the efficiency of ATP competition for pyridinylimidazole inhibitor binding. Biochemistry 37: 13846-13853, 1998.

28. Young PR, McLaughlin MM, Kumar S, Kassis S, Doyle ML, McNulty D, Gallagher TF, Fisher S, McDonnell PC, Carr SA Huddleston MJ, Seibel G, Porter TG, Livi GP, Adams JL and Lee JC: Pyridinyl imidazole inhibitors of p38 mitogen-activated protein kinase bind in the ATP site. J Biol Chem 272: 12116-12121, 1997.

29. Keyse SM and Tyrrell RM: Hemeoxygenase is the major 32-kDa stress protein induced in human skin fibroblasts by UVA radiation, hydrogen peroxide, and sodium arsenite. Proc Natl Acad Sci USA 86: 99-103, 1989.

30. Lau AT, Wang Y and Chiu JF: Reactive oxygen species: current knowledge and applications in cancer research and therapeutic. J Cell Biochem 104: 657-667, 2008.

31. Kobayakawa J, Sato-Nishimori F, Moriyasu M and Matsukawa Y: G2-M arrest and antimitotic activity mediated by casticin, a flavonoid isolated from Viticis Fructus (Vitex rotundifolia Linne fil.). Cancer Lett 208: 59-64, 2004.

32. Li J, Chen P, Sinogeeva N, Gorospe M, Wersto RP, Chrest FJ, Barnes J and Liu Y: Arsenic trioxide promotes histone H3 phosphoacetylation at the chromatin of CASPASE-10 in acute promyelocytic leukemia cells. J Biol Chem 277: 49504-49510, 2002 .

33. Waring P, Khan T and Sjaarda A: Apoptosis induced by gliotoxin is preceded by phosphorylation of histone $\mathrm{H} 3$ and enhanced sensitivity of chromatin to nuclease digestion. J Biol Chem 272: 17929-17936, 1997.

34. Clayton AL and Mahadevan LC: MAP kinase-mediated phosphoacetylation of histone $\mathrm{H} 3$ and inducible gene regulation. FEBS Lett 546: 51-58, 2003.

35. Lee YJ and Shukla SD: Histone H3 phosphorylation at serine 10 and serine 28 is mediated by p38 MAPK in rat hepatocytes exposed to ethanol and acetaldehyde. Eur J Pharmacol 573: 29-38, 2007.

36. Kuruüzüm-Uz A, Güvenalp Z, Ströch K, Demirezer LO and Zeeck A: Antioxidant potency of flavonoids from Vitex agnuscastus $\mathrm{L}$. growing in Turkey. FABAD J Pharm Sci 33: 11-16, 2008.

37. Jozkowicz A, Was H and Dulak J: Heme oxygenase-1 in tumors: is it a false friend? Antioxid Redox Signal 9: 2099-2117, 2007.

38. Hill M, Pereira V, Chauveau C, Zagani R, Remy S, Tesson L, Mazal D, Ubillos L, Brion R, Asghar K, Mashreghi MF, Kotsch K, Moffett J, Doebis C, Seifert M, Boczkowski J, Osinaga $\mathrm{E}$ and Anegon I: Heme oxygenase-1 inhibits rat and human breast cancer cell proliferation: mutual cross inhibition with indoleamine 2,3-dioxygenase. FASEB J 19: 1957-1968, 2005.

39. Sánchez Y, Amrán D, Fernández C, de Blas E and Aller P: Genistein selectively potentiates arsenic trioxide-induced apoptosis in human leukemia cells via reactive oxygen species generation and activation of reactive oxygen species-inducible protein kinases (p38-MAPK, AMPK). Int J Cancer 123: 1205-1214, 2008. 